\title{
Emotional dimension of quality of life and related factors for a sample of Egyptian infertile females attending the international islamic center
}

\author{
Abeer A. Almowafy ${ }^{1}$, Nahed H. Abdel-Fattah ${ }^{2}$, Zeinab E. Hammour ${ }^{2}$ \\ ${ }^{1}$ International Islamic Center for Population Studies and Research, Cairo, Al-Azhar University, Egypt. \\ ${ }^{2}$ Public Health and Community Medicine Department, Faculty of Medicine for Girls, Cairo, Al-Azhar University, Egypt.
}

\section{ABSTRACT}

Background: Infertility in most cultures across the world is considered as a stain and shame which leads to the infertile women suffering. It also affects all features of their quality of life (QOL). Measuring the QOL is a benchmark in today's world of medicine.

Objective: to determine emotional aspect of QOL and related factors among Egyptian infertile females attending IICPSR, Al-Azhar University.

Methodology: this is an analytical cross-sectional study, conducted on 320 infertile women attending the International Islamic Center for population Studies and Research (IICPSR)- Al-Azhar University. Data were collected via the QOL Questionnaire of Infertile females. Socio-demographic data also were inquired and the collected data was analyzed using descriptive and analytical statistics (SPSS 19 program).

Results: data analysis revealed that the mean age of the participants was $28.99 \pm 3.9$, mean duration of marriage was $4.7 \pm 2.7$, of all the studied women $167(52.2 \%)$ were employed, $245(76.55 \%)$ obese or overweight, and $194(60.6 \%)$ were living in rural area. Positive, neutral, and negative scores of QOL of infertile females were discovered among $(44.1 \%),(43.1 \%),(12.8 \%)$ individuals respectively.

Conclusion: Infertility has a major effect on the emotional status of the infertile women. Age of infertile females, body mass index, frequency of treatment and level of education, are found to be the most important factors affecting the QOL.

JRAM 2021; 2 (1): 46-53

Keywords: Females, infertility, quality of life.

Submission Date: 15 June 2020

Acceptance Date: 2 September 2020

Corresponding author: Abeer Abd Elwahed Almowafy. public health department; international islamic center for population studies and research, Cairo, Al-Azhar University, Egypt. Tel.: 01099973094. E-mail: drabeerabdlwahed@gmail.com

Please cite this article as: Almowafy AA, Abdel-Fattah NH, and Hammour ZE. Emotional dimension of quality of life and related factors for a sample of Egyptian infertile females attending the international islamic center. JRAM 2021; 2 (1): 46-53. DOI: 10.21608/jram.2020.35128.1069

\section{INTRODUCTION}

Pregnancy and childbearing are valued roles for females in several industrialized and developing countries ${ }^{[1]}$. Infertility is well-defined as the failure to conceive although regularity in the intercourse for 12 months ${ }^{[2]}$. It has been described that infertility influence $10-15 \%$ of couples in commercial nations in the age between 18-45 years, many of whom are under extreme stress ${ }^{[3-4]}$. Infertile females report worse married adjustment and QOL than the fertile [5]. Infertility can cause several social problems and psychological disturbance such as anxiety, depression, sexual dysfunction and social isolation ${ }^{[6]}$. In general,

https://jram.journals.ekb.eg

Print ISSN 2636-252X - Online ISSN 2636-2538 infertile women may suffer from diminished QOL ${ }^{[7]}$. Quality of life is one of the most essential components of health. The conception of QOL is well-defined in different methods.

World Health Organization's structured six domains to assess QOL: physical, emotional, the level of independence, social, environment and spirituality, religion, or personal beliefs ${ }^{[8]}$. Factors expecting QOL may vary in altered infertile people, genders, traditional, socioeconomic status and other nonmedical conditions ${ }^{[9]}$. Thus, the aim of this work was 
to determine Emotional aspect of QOL and related factors among Egyptian infertile females attending IICPSR, Al-Azhar University.

\section{SUBJECTS AND METHODS}

\section{Study design and setting:}

This is analytical cross-sectional study. The study group consisted of 320 infertile Egyptian women referring to IICPSR, Al-Azhar University during a period of 3 months from 1/11/2018 to 30/1/2019.

\section{Sampling technique: \\ -Sample type:}

The study sample was selected from Egyptian females complaining of infertility attending IICPSR through convenience sampling, taking into consideration the inclusion criteria (females who diagnosed with primary infertility in this center, accepted to participate in the research and completed the questionnaires).

\section{-Sample size:}

A sample size of 320 females, was calculated using Epi-Info version 7 program (300 female), based on the average rate of IICPSR attendants' females (2000 / year), using confidence limit of $95 \%$ and confidence interval of $5 \%$. This center carries out population and reproductive health studies and research in the Muslim World. It consists of different departments that were established for management of infertility. Its activities for all over Egypt.

\section{Study Tools:}

The collection of data was a two-part questionnaire (in one setting).

A. The first part: deal with demographic information (socioeconomic status (high -middle - low - very low), education level, marriage duration, occupation, age of female and residence).

B. The second part: fertility quality of life (FertiQoL) questionnaire, there is two versions of questionnaire (Arabic and English) ${ }^{[10-14]}$. In this research utilized Arabic version of QOL questionnaire was utilized. Emotional domain only contains 6 items which was used scored (five choice) according to Likert scale, the response scale has a range of 0 to 4 . (www.fertiqol.org). the validity and reliability of this questionnaire were confirmed with the Cronbach's alpha of 0.81 and a test-retest reliability coefficient of 0.89 for the whole questionnaire ${ }^{[15]}$. "Each question had five choices: completely agree, agree, no idea, disagree, and completely disagree. Some questions dealt with positive and some others considered negative features in the study participants. The questions were scored as follows: 0 to 4 points were awarded for answers to questions dealing with positive features, from 'completely agree' to 'completely disagree', respectively. Similarly, 0 to
4 points were awarded for answers to questions dealing with negative features, from 'completely agree' to 'completely disagree', respectively. Then, the summed scores were converted to a percentage of the total score and interpreted in the following manner: 'very negative' QOL received less than $20 \%$ of the total score; 'negative' QOL was $\geq 20 \%$ but $<40 \%$ of the total score; 'neutral' QOL was $\geq 40 \%$ but $<60 \%$ of the total score; 'positive' QOL was $\geq 60 \%$ but $<80 \%$ the total score; and 'very positive' QOL was $\geq 80 \%$ of the total score. In other words, the scores of QOL questionnaire in each area were between 0 and 100 , and a higher score indicated a better QOL in that certain area ${ }^{[16]}$.

C. Measurements: Body Mass Index (BMI) was calculated according to the equation (Weight $(\mathrm{kg}) /$ Height2 (cm) "Underweight $(<18.5)$ - Normal weight (18.5-24.9)- Overweight (25-29.9) Obese $(\geq 30)^{[17]}$

The research was approved by the IRB committee of Faculty of Medicine "Girls" Al-Azhar University. All the necessary approvals for carrying out the research were obtained from IICPSR. Before giving questionnaire for the females: It was clearly stated that the study is conducted as a step in the researcher's Doctorate degree. Oral consent from each female was obtained after proper orientation about objectives of the study. Confidentiality of data will be considered in all levels of the study. Collected data will not be used for any other purpose.

\section{Statistical analysis}

The collected data were entered to the computer and analyzed by using SPSS program (version 19). Relation between QOL (emotional) and all variables in infertile females were carried out using Pearson Chi square- test and linear regression analysis. The level of significance was taken at 0.05 . "So, $\mathrm{p}$ value $>0.05$ was insignificant and p value $\leq 0.05$ was significant".

\section{RESULTS}

The mean age of the study group was $28.99 \pm 3.9$ years, mean duration of marriage was $4.7 \pm 2.7$, $(52.2 \%)$ were employed, and $(76.5 \%)$ were obese or overweight. Regarding the residence $60.6 \%$ were living in rural area (Table 1).

The score evaluating QOL of infertile females demonstrated that the mean total score was $56.7 \pm$ 12.9. Where, QOL was positive in $44.1 \%$ of the studied sample, while $43.1 \%$ and $12.8 \%$ were neutral and positive respectively (Figure 1).

Data of table revealed that $20 \%$ of the studied patients were completely able to cope with their fertility problem while $60 \%$ were not tolerating with that 
problem. Nearly half of the women (52\%) always feel jealousy and resentment, experience grief (58\%), fluctuate between hope \& despair (46\%); while $51 \%$ their fertility problem make them angry very much (Table 2).

The analysis of this table revealed that there is a significant statistical difference between all the variables of the infertile women and emotional subscale of quality of life scores except, for employment status and social score (Table 3). The linear regression analysis of emotional subscale of quality of life score versus the different variables of infertile women showed that there is a relevant significant statistical relation with BMI and educational status, while the relation not significant with other variables (Table 4).

Table (1): General characteristics of the studied group

\begin{tabular}{|c|c|c|}
\hline Variables & No. (320) & $\%$ \\
\hline $\begin{array}{l}\text { Age groups } \\
\quad<30 \text { years } \\
\geq 30 \text { years }\end{array}$ & $\begin{array}{l}205 \\
115\end{array}$ & $\begin{array}{l}64.1 \\
35.9\end{array}$ \\
\hline $\begin{array}{l}\text { Age /years } \\
\text { Mean } \pm \text { SD } \\
\text { Range }\end{array}$ & \multicolumn{2}{|c|}{$\begin{array}{c}28.99 \pm 3.9 \\
22\end{array}$} \\
\hline $\begin{array}{l}\text { BMI } \\
\text { Under weight } \\
\text { Normal weight } \\
\text { Overweight } \\
\text { Obese }\end{array}$ & $\begin{array}{c}2 \\
73 \\
98 \\
147\end{array}$ & $\begin{array}{r}0.6 \\
22.8 \\
30.6 \\
45.9\end{array}$ \\
\hline $\begin{array}{l}\text { Duration of marriage (years) } \\
\text { Less than } 5 \\
5-10 \\
\text { More than } 10\end{array}$ & $\begin{array}{c}226 \\
84 \\
10\end{array}$ & $\begin{array}{c}70.6 \\
26.3 \\
3.1\end{array}$ \\
\hline $\begin{array}{l}\text { Duration of marriage } \\
\text { Mean } \pm \text { SD } \\
\text { Range }\end{array}$ & \multicolumn{2}{|c|}{$\begin{array}{c}4.7 \pm 2.7 \\
15\end{array}$} \\
\hline $\begin{array}{l}\text { Origin } \\
\text { Urban } \\
\text { Rural }\end{array}$ & $\begin{array}{l}126 \\
194\end{array}$ & $\begin{array}{l}39.4 \\
60.6\end{array}$ \\
\hline $\begin{array}{l}\text { Social score } \\
\text { Very low } \\
\text { Low } \\
\text { Middle }\end{array}$ & $\begin{array}{c}119 \\
140 \\
61\end{array}$ & $\begin{array}{l}37.2 \\
43.8 \\
19.1\end{array}$ \\
\hline
\end{tabular}

Table (2): The response of the studied group to the questionnaire measuring Emotional domain of Fertility quality of life

\begin{tabular}{|c|c|c|c|c|c|c|}
\hline The response & \multicolumn{2}{|c|}{ Completely } & \multicolumn{2}{|c|}{ Moderately } & \multicolumn{2}{|c|}{ Not at all } \\
\hline Emotional questionnaire & No. & $\%$ & No. & $\%$ & No. & $\%$ \\
\hline Do you feel able to cope with your fertility problems? & 64 & $20 \%$ & 64 & $20 \%$ & 192 & $60 \%$ \\
\hline The response & \multicolumn{2}{|c|}{ Always } & \multicolumn{2}{|c|}{ Quite often } & \multicolumn{2}{|c|}{ Never } \\
\hline $\begin{array}{l}\text { Do your fertility problems cause feelings of jealousy } \\
\text { and resentment? }\end{array}$ & 168 & $52 \%$ & 48 & $15 \%$ & 104 & $33 \%$ \\
\hline $\begin{array}{l}\text { Do you experience grief and/or feelings of loss about } \\
\text { not being able to have a child (or more children)? }\end{array}$ & 187 & $58 \%$ & 51 & $16 \%$ & 82 & $26 \%$ \\
\hline $\begin{array}{l}\text { Do you fluctuate between hope and despair because of } \\
\text { fertility problems? }\end{array}$ & 148 & $46 \%$ & 58 & $18 \%$ & 114 & $36 \%$ \\
\hline The response & \multicolumn{2}{|c|}{ Very much } & \multicolumn{2}{|c|}{ Moderate } & \multicolumn{2}{|c|}{ Not at all } \\
\hline $\begin{array}{l}\text { Do you feel sad and depressed about your fertility } \\
\text { problems? }\end{array}$ & 104 & $32 \%$ & 120 & $38 \%$ & 96 & $30 \%$ \\
\hline Do your fertility problems make you angry? & 162 & $51 \%$ & 56 & $17 \%$ & 102 & $32 \%$ \\
\hline
\end{tabular}


Table (3): The relation between Emotional subscale and some variables of infertile women

\begin{tabular}{|c|c|c|c|c|c|c|}
\hline \multirow{3}{*}{ Variables of infertile women } & \multicolumn{6}{|c|}{ Emotional subscale } \\
\hline & \multirow{2}{*}{$\begin{array}{c}\text { Total No. } \\
\quad(320)\end{array}$} & \multirow{2}{*}{$\begin{array}{l}\text { Negative } \\
\text { No. }(\%)\end{array}$} & \multirow{2}{*}{$\begin{array}{l}\text { Neutral } \\
\text { No. }(\%)\end{array}$} & \multirow{2}{*}{$\begin{array}{l}\text { Positive } \\
\text { No. }(\%)\end{array}$} & \multicolumn{2}{|c|}{$\begin{array}{c}\text { Test of } \\
\text { Significance }\end{array}$} \\
\hline & & & & & chi $=\chi^{2}$ & p \\
\hline $\begin{array}{l}\text { Age groups: } \\
\quad<30 \text { years } \\
\geq 30 \text { years }\end{array}$ & $\begin{array}{l}184 \\
136\end{array}$ & $\begin{array}{l}64(34.8) \\
29(21.3)\end{array}$ & $\begin{array}{l}53(28.8) \\
59(43.4)\end{array}$ & $\begin{array}{l}67(36.4) \\
48(35.3)\end{array}$ & 9.6 & $0.001^{*}$ \\
\hline $\begin{array}{l}\text { BMI } \\
\text { Normal weight } \\
\text { Overweight } \\
\text { Obese }\end{array}$ & $\begin{array}{c}91 \\
115 \\
114\end{array}$ & $\begin{array}{c}33(36) \\
37(32.2) \\
23(20.2)\end{array}$ & $\begin{array}{l}37(40.7) \\
30(26.1) \\
45(39.5)\end{array}$ & $\begin{array}{l}21(23.3) \\
48(41.7) \\
46(40.4)\end{array}$ & 15.5 & $0.01^{*}$ \\
\hline $\begin{array}{l}\text { Educational status } \\
\text { Illiterate } \\
\text { Read and write } \\
\text { Primary and preparatory } \\
\text { Secondary } \\
\text { Higher education }\end{array}$ & $\begin{array}{l}44 \\
50 \\
54 \\
87 \\
85\end{array}$ & $\begin{array}{c}9(20.5) \\
13(26) \\
18(33.3) \\
33(37.9) \\
20(23.5)\end{array}$ & $\begin{array}{c}17(38.6) \\
9(18) \\
16(29.6) \\
24(27.6) \\
46(54.1)\end{array}$ & $\begin{array}{c}18(40.9) \\
28(56) \\
20(37) \\
30(34.5) \\
19(22.4)\end{array}$ & 30 & $0.001^{*}$ \\
\hline $\begin{array}{l}\text { Employment: } \\
\text { Unemployed } \\
\text { Employed }\end{array}$ & $\begin{array}{l}153 \\
167\end{array}$ & $\begin{array}{l}47(30.7) \\
46(27.5)\end{array}$ & $\begin{array}{l}47(30.7) \\
65(38.9)\end{array}$ & $\begin{array}{l}59(38.6) \\
56(33.5)\end{array}$ & 2.3 & 0.30 \\
\hline $\begin{array}{l}\text { Presence of any chronic disease } \\
\text { Yes } \\
\text { No }\end{array}$ & $\begin{array}{l}171 \\
149\end{array}$ & $\begin{array}{l}42(24.6) \\
51(34.2)\end{array}$ & $\begin{array}{l}71(41.5) \\
41(27.5)\end{array}$ & $\begin{array}{c}58(33.9) \\
57(38.3)\end{array}$ & 7.4 & $0.02^{*}$ \\
\hline $\begin{array}{l}\text { Previously received any } \\
\text { treatment for infertility } \\
\text { Yes } \\
\text { No }\end{array}$ & $\begin{array}{l}156 \\
164\end{array}$ & $\begin{array}{l}55(35.3) \\
38(23.2)\end{array}$ & $\begin{array}{l}52(33.3) \\
60(36.6)\end{array}$ & $\begin{array}{l}49(31.4) \\
66(40.2)\end{array}$ & 5.9 & $0.05^{*}$ \\
\hline $\begin{array}{l}\text { Socioeconomic status } \\
\text { Very low } \\
\text { Low } \\
\text { Middle }\end{array}$ & $\begin{array}{l}113 \\
128 \\
79\end{array}$ & $\begin{array}{l}36(31.9) \\
36(28.1) \\
21(26.6)\end{array}$ & $\begin{array}{l}37(32.7) \\
44(34.4) \\
31(39.2)\end{array}$ & $\begin{array}{l}40(35.4) \\
48(37.5) \\
27(34.2)\end{array}$ & 1.2 & 0.80 \\
\hline $\begin{array}{l}\text { Residence } \\
\text { Urban } \\
\text { Rural }\end{array}$ & $\begin{array}{l}126 \\
194\end{array}$ & $\begin{array}{l}37(29.4) \\
56(28.9)\end{array}$ & $\begin{array}{l}45(35.7) \\
67(34.5)\end{array}$ & $\begin{array}{l}44(34.9) \\
71(36.6)\end{array}$ & 0.09 & 0.9 \\
\hline
\end{tabular}

"Statistically significant difference $\mathrm{p} \leq 0.05$, the table represents a row percentage

Table (4): Linear regression analysis of emotional subscale of quality of life scores versus the different variables of infertile women

\begin{tabular}{|l|c|c|}
\hline \multicolumn{1}{|c|}{ Different variables of infertile women } & B-Coefficient & P value \\
\hline BMI & 0.13 & $0.01^{*}$ \\
\hline Educational status & -0.07 & $0.03^{*}$ \\
\hline Previously received any treatment for infertility & 0.13 & 0.14 \\
\hline Age & 0.01 & 0.17 \\
\hline Suffering from chronic disease & -0.09 & 0.32 \\
\hline
\end{tabular}




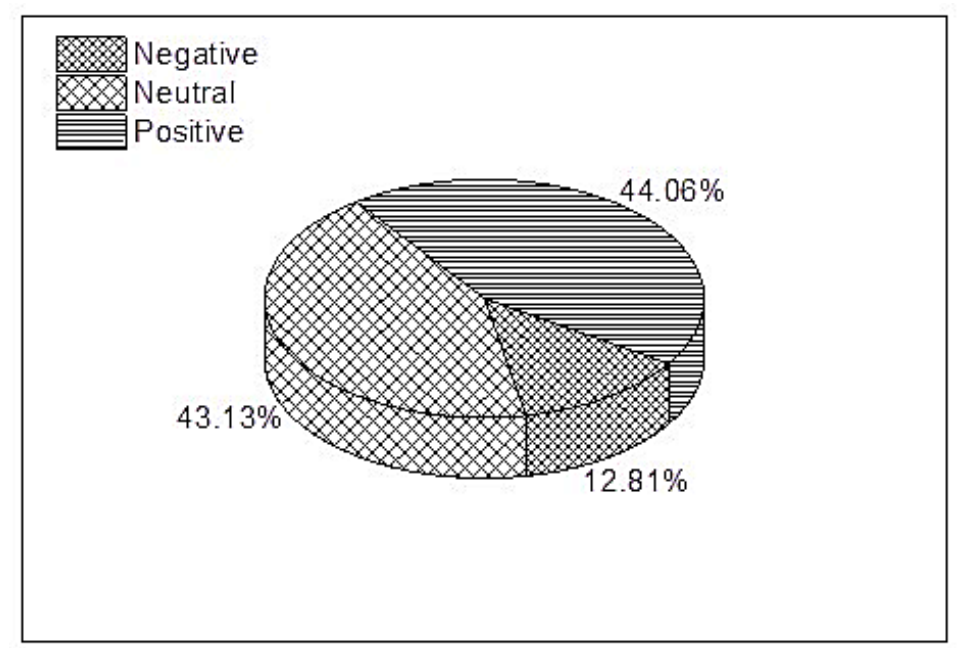

Figure (1): Distribution of the infertile women group according to the emotional quality of life score

\section{DISCUSSION}

Quality of life has become one of the most important concerns today and is seen as one of the measurable criteria for assessment of treatment. Assessment of QOL helps establish an effective connection between a patient and her treatment team, different ways of treatments helps infertile persons make informed decisions about treatment devices. Measurement of QOL makes it possible to recognize the needs of the clients and thus improve the quality of provide facilities ${ }^{[14]}$. Development of infertile females' quality of life can create satisfied families and established society ${ }^{[18]}$. Therefore, the present study was conducted to evaluate the quality of life among sample of infertile females (320) selected from the attendance of the (IICPSR) at Al-Azhar University. It was found that, the mean FertiQoL score was $56.7 \pm 12.9$ which is lower than what was reported in other studies ${ }^{[19-20]}$, but higher than what was reported in the research conducted in Netherlands by Aarts et al. ${ }^{[21]}$.

In the present study, $44.1 \%$, have a positive quality of life score compared to $43.1 \%$, and $12.8 \%$ with neutral and negative quality of life, respectively. These findings agree with a descriptive-correlational study conducted in Iran, Zahra et al. ${ }^{[22]}$ which establish that $34.6 \%$, and $63.3 \%$, had neutral and, positive quality of life, respectively. Also, the results are in accordance with results of Indian research ${ }^{[23]}$ which reported that $52.1 \%$ of the infertile women had positive quality of life, and $37.8 \%$ had neutral quality of life.

The examination of the existing study displayed that the age of infertile woman had an effect on the emotional domain, as the emotional domain between younger infertile females $(<30$ years) was establish to be significantly better than that of the older one $(>30$ years). This finding may be explained by a crosssectional descriptive study reported in Iran. Rezaei et al. ${ }^{[24]}$ which clarified that a young woman has more chances to conceive and obtain altered medical issues, than an older one. Similarly, Khayata et al. ${ }^{[25]}$ in Erbil city (Iraq); found a significant difference in the relation between QOL and age. The QOL of infertile females is reduced over time when they get older, may be because the older females may expose to more trials of treatments and in turn more failures and stress.

The current study indicated that, previously received any treatment for infertility have a significant effect on emotional domain. These findings are in accordance with the study conducted by Rimaz et al. in New York ${ }^{[26]}$ which proved that higher frequency of infertility's treatment imposed more stress and pressure is imposed on females which result in a reduction in emotional domain level.

Regarding the chronic diseases the present study showed that women without chronic disease have a better emotional health scores compared to those suffering of chronic disease. This is in agreement with Rooney et al. [27] "who found that woman without chronic disease had a significant relationship with almost all dimensions of quality of life; if infertility is added, negative affect to those aspects of a woman's quality of life is more likely to present, so managing the mentioned conditions may lead to a relatively better quality of life".

The results of this study revealed that there is a significant difference with emotional subscale of FertiQoL in terms of education level, as the higher the education level, the lower the emotional subscale. Similar finding was detected by the study of Maroufizadeh et al in Iran ${ }^{[28]}$, they found that infertile woman with a relatively low educational level has higher QOL. The woman with low education usually played excessive role as housewife, so she enjoyed a greater social health, and receives more social support 
due to good relationships with family. In fact, an excellent social support can develop the mental and physical health; thus, it provides a relatively high social well-being and good QOL ${ }^{[24]}$. In the other hand, research conducted by Seyedi et al. in Turkey ${ }^{[29]}$ found that no significant difference between sociodemographic characteristics and emotional domain of QOL.

In the current study, no significant difference was found between employment and emotional subscale of FertiQoL. In contrast with our research, the finding of a study conducted in Turkey by Çavdar et al. ${ }^{[30]}$; revealed that working infertile women had both higher point of self-esteem and QOL.

\section{CONCLUSIONS}

FertiQoL is potentially useful measures of infertility related QOL. Infertility had a negative effect on the emotional status of the infertile women. Age of infertile females, body mass index, frequency of treatment and level of education, are found to be the most important factors affecting the QOL.

Financial support: No financial support.

Conflicts of interest: There are no conflicts of interest.

\section{Acknowledgement}

We would like to acknowledge the staff members of community medicine department, Faculty of Medicine (for Girls) Al-Azhar University for their generous help in completing this research. Also, we thank the participants in this research for their cooperation.

\section{REFERENCES}

1. Direkvand-Moghadam A, Delpisheh A, Montazeri A, Sayehmiri K. Quality of life among Iranian infertile women in postmenopausal period: a cross sectional study. J Menopausal Med 2016; 22(2): 108-13.

2. Sezgin H, Hocaoglu C, Guvendag-Guven ES. Disability, psychiatric symptoms, and quality of life in infertile women: a cross-sectional study in Turkey. Shanghai arc psychiatry 2016; 28(2): 8694.

3. Dural O, Yasa C, Keyif B, Celiksoy H, Demiral I, YukselOzgor B, et al. Effect of infertility on quality of life of women: a validation study of the Turkish FertiQoL. Hum Fertil 2016; 19(3): 18691.

4. Klemetti R, Raitanen J, Sihvo S, Saarni S, Koponen P. Infertility, mental disorders and wellbeing-a nationwide survey. Acta Obstet Gynecol Scand 2010; 89(5): 677-82.

5. Goldberg DP, Hillier VF. A scaled version of the general health questionnaire. Psychol Med 1979; 9(1):139-45.

6. Baghiani MMH, Aminian AH, Abdoli AM, Seighal N, Falahzadeh $\mathbf{H}$, Ghasemi N.
Evaluation of the general health of the infertile couples. Iran J Reprod Med. 2011; 9(4): 309-14.

7. Lo SS, Kok WM. Sexual functioning, and quality of life of Hong Kong Chinese women with infertility problem. Hum Fertile (Camb). 2016; 19(4): 268-74.

8. Krägeloh CU, Billington DR, Henning MA, Chai PPM. Spiritual quality of life and spiritual coping: Evidence for a two-factor structure of the WHOQOL spirituality, religiousness, and personal beliefs module. Health and Quality of Life Outcomes. 2015; 13(26): 1-11

9. Noorbala AA, Mohammad K. The validation of general health questionnaire 28 as a psychiatric screening tool. Hakim Health Sys Res 2009; 11(4): 47-53.

10. http://sites.cardiff.ac.uk/fertiqol/files/2015/02/fe rtiqol-Arabic.pdf

11. http://sites.cardiff.ac.uk/fertiqol/files/2015/02/fe rtiqol-English.pdf

12. Xiaoli S, Mei L, Junjun B, Shu D, Zhaolian W, Jin W, et al. Assessing the quality of life of infertile Chinese women: a cross sectional study. Taiwan J Obstet Gynecol 2016; 55(2):244-50.

13. Pei-Yang $H$, Ming-Wei $L$, Jiann-Loung $H$, Maw-Sheng L, Meng-Hsing W. The fertility quality of life (FertiQoL) questionnaire in Taiwanese infertile couples. Taiwan J Obstet Gynecol 2013; 52(2): 204-9.

14. Samah MAM, Yousif A, Inaam A. Quality of life of infertile couples at Mansoura university hospital. Port Said Scientific Journal of Nursing 2019; 6(1): 229-243.

15. Yaghmaei F, Mohammadi S, Alavimajd $H$. Developing "Quality of life in infertile couples' questionnaire" and measuring its psychometric properties. J Reprod Infertil 2009; 10(2):137-43.

16. Azam N, Mohammad MN, Marziyeh Z, Farideh Y, Mohammad HS. Quality of life and general health of infertile women. Health and Quality of Life Outcomes 2017; 15: 139.

17. Moreault $O$, Lacasse, $Y$, Bussières JS. Calculating ideal body weight: Keep it simple. Anesthesiology 2017;127(1): 203-204.

18. Parnian R, Poorgholami F, Parandavar N, Jamali S, Shakeri F. A comparative study of ouality of life in infertile and fertile women referred to Jahrom infertility clinics. Global Journal of Health Science 2017; 9(4): 174-181.

19. Aarts JWM, Van Empe IWH, Boivin J, Nelen WL, Kremer JAM, Verhaak CM. Relationship between quality of life and distress in infertility: a validation study of the Dutch FertiQoL. Human Reproduction 2011; 26(5):1112-1118.

20. Hatice KS, Petek BK. Quality of life in women with infertility via the FertiQoL and the hospital anxiety and depression scales. Nurs Health Sci 2015; 17(1): 84-89 
21. Aarts JWM, Huppelschoten AG, Empe IWH, Boivin J, Verhaak CM, Kremer JAM, et al. How patient-centered care relates to patients' quality of life and distress: a study in 427 women experiencing infertility. Human Reproduction 2011; 0(0): 1-8.

22. Zahra R, Mohammad H, Mahboubeh V, Farideh Y, Athareh KS, Jamileh KM. predictors of quality of life in infertile couples. Journal of Menopausal Medicine 2019; 25: 35-40.

23. Barani DG, Thiyagarajan S, Nigesh. Role of infertility, emotional intelligence, and resilience on marital satisfaction among Indian couples. International Journal of Applied Psychology 2013; 3(3): 31-37.

24. Rezaei N, Azadi A, Zargousi R, Sadoughi Z, Tavalaee Z, Rezayati M. Maternal health-related quality of life and its predicting factors in the postpartum period in Iran. Hindawi Publishing Corporation Scientifica 2016; 1-7.

25. Khayata KA, Masoomi SZ, Mousavi SA, Poorolajal J, Shobeiri F, Hazavhei SM. Quality of life and its related factors in infertile couples.
Journal of Research in Health Sciences 2014; 14(1): 59-66.

26. Rimaz SH, Dastoorpoor M, Vesali S, Saiepour N, Beigi Z, Nedjat $S$. The survey of quality of life and its related factors in female-headed households supported by Tehran Municipality, District. Iran J Epidemiol 2014; 10(2): 4855.

27. Rooney KL, Domar AD. The impact of stress on fertility treatment. Curr Opin Obstet Gynecol 2016; 28(3): 198-201.

28. Maroufizadeh S, Karimi E, Vesali S, Omani SR. Anxiety, and depression after failure of assisted reproductive treatment among patients experiencing infertility. Int $\mathbf{J}$ Gynaecol Obstet 2015; 130(3): 253-6.

29. Seyedi AST, Sadeghi K, Bakhtiari M, Ahmadi SM, Nazari AA, Khayatan T. Effect of group positive psychotherapy on improvement of life satisfaction and the quality of life in infertile woman. Int J Fertil Steril 2016; 10: 105-12.

30. Çavdar NK, Coskun AM. The effect of infertility upon quality of life and self-esteem. MOJ Women's Health 2018; 7(3): 89-94. 


\section{الملخص العربي}

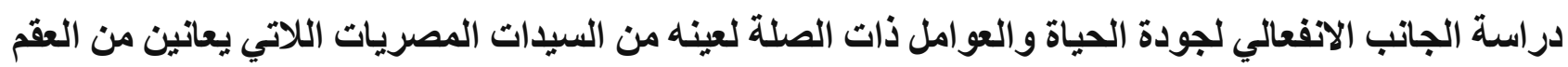

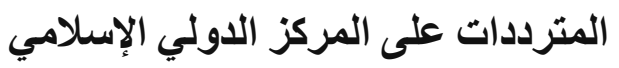

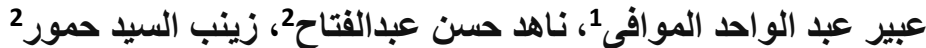

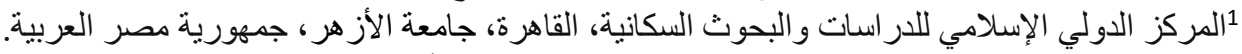

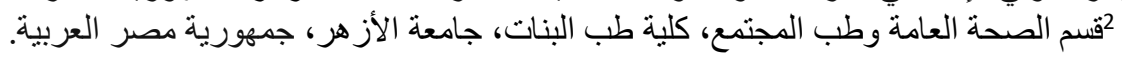

ملخص البحث

الخلفية: العقم هو عدم حدوث الحمل بعد 12 شهرا أو أكثر من الاتصال الجنسي المنتظم. العقم مشكله عالميه

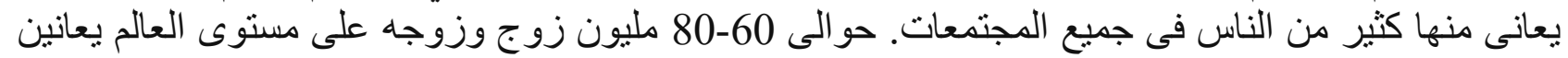

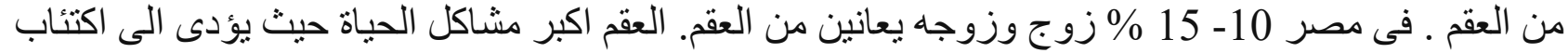
و عزله اجتماعيه وخلل فى الوظائف الجنسية .

الهـف :تقييم جودة الحياة خاصة الجانب الانفعالي و التعرف على العوامل التي تؤثر على جودة الحياة للسيدات

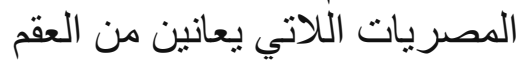

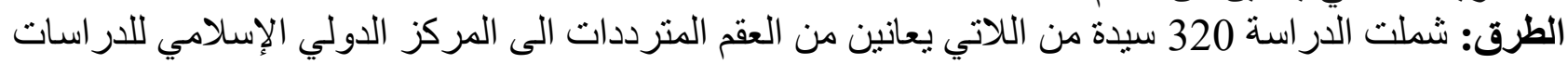

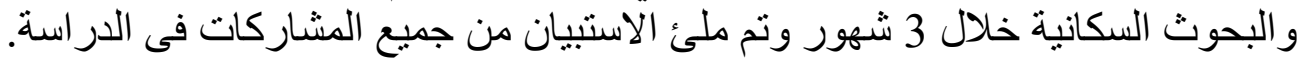
النتائج :أثتبت الدراسة أن التقدم فى السن و إنخفاض مستوى التعليم و الإقامة في الريف والحالة الاجتماعية و الاقتصادية المنخفضة من العوامل التي تؤثر سلبيا على الجانب الانفعالي لجودة الحئي الحياة. الاستنتاجات : العق لله اثار سلبيه على الحالة الانفعالية والنفسية للسيدات ويؤثز على جودة الحياة . الكلمات المفتاحية: السيدات، العقم، جودة الحياة الباحث الرئيسي الأسم: عبير عبد الواحد المو افق، المركز الدولي الإسلامي للار اسات و البحوث السكانبة، القاهرة جامعة الأزهر، جمهورية مصر العربية

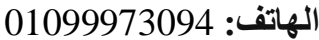
البريد الإكتروني: gmail.com 